University of Nebraska - Lincoln

DigitalCommons@University of Nebraska - Lincoln

3-2-2002

\title{
The Effects of Defendant Remorse on Mock Juror Decisions in a Malpractice Case
}

Brian H. Bornstein

University of Nebraska-Lincoln, bbornstein2@unl.edu

Lahna M. Rung M.A.

Monica K. Miller

University of Nebraska-Lincoln, mkmiller@unr.edu

Follow this and additional works at: https://digitalcommons.unl.edu/psychfacpub

Part of the Psychiatry and Psychology Commons

Bornstein, Brian H.; Rung, Lahna M. M.A.; and Miller, Monica K., "The Effects of Defendant Remorse on Mock Juror Decisions in a Malpractice Case" (2002). Faculty Publications, Department of Psychology. 187.

https://digitalcommons.unl.edu/psychfacpub/187

This Article is brought to you for free and open access by the Psychology, Department of at DigitalCommons@University of Nebraska - Lincoln. It has been accepted for inclusion in Faculty Publications, Department of Psychology by an authorized administrator of DigitalCommons@University of Nebraska - Lincoln. 


\title{
The Effects of Defendant Remorse on Mock Juror Decisions in a Malpractice Case
}

\author{
Brian H. Bornstein, Ph.D., M.L.S., Lahna M. Rung, M.A., \\ and Monica K. Miller, B.A.
}

\begin{abstract}
The purpose of this study was to observe the effects of defendant remorse on monetary damages awarded to a plaintiff in a malpractice case. In two experiments, the physician-defendant expressed remorse at the time of the incident and again at trial, expressed remorse at trial, explicitly demonstrated a lack of remorse at trial, or made no mention of remorse (or a lack thereof). Participants decided how much money to award to the plaintiff and evaluated both the plaintiff and the defendant on several dimensions. Participants awarded greater compensation when the physician expressed remorse at the time of the incident than in the other conditions, both when the plaintiff was the injured patient's spouse in a wrongful death suit (experiment 1) and when the patient sued on his own behalf (experiment 2). This effect of remorse was greater for males than for females (experiment 1 ) and for relatively severely injured plaintiffs (experiment 2 ).
\end{abstract}

Malpractice suits against physicians are a prominent and contentious feature of the American civil justice system (see, e.g., Vidmar, 1995). Physicians are indeed responsible for the welfare of their patients. However, as human beings they are apt to make mistakes. When mistakes are made in most social situations, the appropriate response is to apologize (Schlenker \& Darby, 1981). Does this social strategy apply to physicians as well, or must they protect themselves from (or in) litigation?

The answer to this question has been up for debate (Cohen, 1999; Fiesta, 1994; Lowes, 1997). Some sources say that apologies are appropriate when medical mis-

Correspondence to: Professor Brian H. Bornstein, 238 Burnett Hall, Department of Psychology, University of Nebraska—Lincoln, Lincoln, NE 68588-0308, U.S.A. E-mail: bbornstein2@unl.edu Brian Bornstein is associate professor of psychology and law at UNL and associate director of the UNL Law/Psychology Program. Lahna Rung is an academic and career counselor at Louisiana State University (LSU). Monica Miller is a graduate student in UNL's Law/Psychology Program, working toward her $\mathrm{PhD}$ and JD degrees. This research began as an undergraduate honors thesis conducted by the second author, under the supervision of the first author. It was presented at the 2001 meeting of the American Psychological Association, where we received the helpful comments of Michael Saks, Alan Tomkins, Roselle Wissler, and Larry Wrightsman. We are also grateful for the research assistance of Andreas Bojesen, Melissa Emler, Becky Norman, and Stephanie Petersen, and for the medical advice of Christie Emler. 
takes are made, as apologizing is the natural and humane thing to do (e.g., Lowes, 1997). Physicians who do apologize may avoid suit altogether because of their honesty. Many injured parties merely seek to find answers to uncertainties surrounding the event that caused injury, to force wrongdoers to take responsibility for their errors, or to encourage the development of measures to prevent future injury (Huycke \& Huycke, 1994; Sloan, 1991). Often, however, the goals of the injured parties are not aligned with the goals of the current adversarial legal system, resulting in plaintiffs receiving monetary awards, but not the intangible rewards they were seeking (Bazemore, 1998; Goren, 2001). Most commentators agree that physicians should never admit fault, because such an admission may actually give patients the idea to sue (Lowes, 1997). Further, the adversarial system discourages wrongdoers from apologizing because it could be used against them in arguing that it is an admission of fault (Cohen, 1999; Goren, 2001).

Cohen (1999) suggests that lawyers should encourage their clients, in some situations, to apologize. His legal analysis concludes that the benefits of apology include a reduced likelihood of being sued, more favorable settlement negotiations, and repaired relationships between the parties. In the case of medical malpractice, a doctor who does not apologize for fear of being sued may inadvertently drive a wedge between himself and the patient, prompting the patient to sue (Cohen, 1999). Cohen suggests that an apology may help to alleviate this tension between the patient and doctor, thereby preventing litigation.

Further, an apology can be conducted in such a way that the patient cannot use the apology against the client in court (Cohen, 1999). Concerns that apologies by physicians might imply negligence, while blocking the flow of information from physicians to patients or their families, have led a few states to pass laws making apologies by physicians inadmissible evidence at trial. For example, a Massachusetts statute provides that

Statements, writings or benevolent gestures expressing sympathy or a general sense of benevolence relating to the pain, suffering or death of a person involved in an accident and made to such person or to the family of such person shall be inadmissible as evidence of an admission of liability in a civil action (Mass. Ann. Laws ch. 233, §23D).

Similar laws exist in Texas (Texas Civil Practice and Remedies Code, §18.061) and California (Cal. Evid. §1160), and judges in some jurisdictions have issued rulings to the same effect. For example, the Vermont Supreme Court held that in a medical malpractice case, an apology by a physician for an "inadequate" operation is not an admission of liability (Phinney v. Vinson, 1992; see also Deese v. Carroll City County Hospital, 1992). Nonetheless, the majority of jurisdictions do allow a physician's apology to be admitted as inculpatory evidence.

Are legal expectations about the effect of an apology supported by empirical evidence? Psychological research on apology has identified four apology strategies that affect perceptions of the transgressor and the effectiveness of the apology (Scher \& Darley, 1997). These strategies include remorse (an expression of sadness about the transgression), responsibility (an admission of fault), forbearance (a promise to avoid the transgression in the future), and reparation (an offer to correct the transgression). A transgressor's feeling of remorse seems to be an especially important component of 
apology, in that "the promise of forbearance, offer of repair and expression of responsibility strategies each had an impact on the amount of remorse that was attributed to the speaker. Even in situations where the remorse expression was not explicit, subjects read the apology as if remorse had been communicated by the speaker" (Scher \& Darley, 1997, p. 138).

Research has been performed focusing on the value of an apology and expressions of remorse in non-legal social situations. Children are taught to apologize when they make a mistake, especially as the consequences of their actions increase (Schlenker \& Darby, 1981), and this lesson is reinforced throughout life. Remorseful children are blamed less, favored more, and recommended for less punishment than non-remorseful children (Darby \& Schlenker, 1989). More generally, apologies are the favored outcome in a variety of social predicaments. They lower a violation's impact on perceptions of the wrongdoer's trustworthiness, character, interpersonal judgment, and likelihood of future transgressions (Gold \& Weiner, 2000; Orleans \& Gurtman, 1984).

Thus, apology and remorse affect many types of judgment, but how exactly does an apology bring about this change? There are two general factors that allow apologies to have such an effect, one involving the implications of an apology for the wrongdoer, and one involving the implications of an apology for the injured party.

The first way in which apologies may influence perceptions and judgments is through impression management. That is, apologies enhance impressions of the wrongdoer and are the most polite, trustworthy, and effective method of resolving interpersonal conflict (Takaku, Weiner, \& Ohbuchi, 2001). People are driven to apologize largely because they strive to see themselves in a certain light. For example, a woman may believe that she is a caring, sensitive person; yet at times these beliefs are threatened, as when the woman hurts someone's feelings. When this happens, several strategies, including apologizing, may be used in order to reestablish that this event was not an indication of the person's true character (Bennett \& Dewberry, 1994). Apologies often invoke a more positive view of the wrongdoer on such traits as likeability and goodness (Darby \& Schlenker, 1989), and criminal offenders who show remorse are also seen as less likely to re-offend (Pipes \& Alessi, 1999).

This shift toward a more positive view of the wrongdoer may be, in part, because an apology connotes that a wrong has been committed but that the wrongdoer has had a change of heart. An apology suggests that the cause of the transgression was not stable and is therefore unlikely to happen again (Weiner, 1986). Thus, a wrongdoer who is remorseful is more likely to be forgiven because the injured party perceives that the wrongdoer is unlikely to repeat the offense (Gold \& Weiner, 2000). Additionally, apology may affect impression management by suggesting that the wrongdoer has already endured suffering and is therefore less deserving of additional punishment (Rumsey, 1976).

The second way in which an apology affects judgments is by creating social constraints that influence the injured party to accept the apology. Goffman (1955) describes an apology as an offering to correct for the wrong and to re-establish order to normal social interaction. This shifts the focus back onto the injured party, who likely recognizes that the socially acceptable reaction is to forgive the wrongdoer (Bennett \& Dewberry, 1994; Takaku et al., 2001). Injured parties, then, are put in a position in which they must either accept the apology or violate normative social dynam- 
ics of personal interaction. Thus, apologies are often accepted because injured parties are under social constraints that encourage them to do so. Because apologies cast the wrongdoer in a more favorable light, and because social norms require the injured party to accept an apology, it is not surprising that judgments made concerning wrongdoers are more positive when the wrongdoer has apologized.

Research has indicated that men and women may perceive apologies in different ways. For example, a study by Gonzales, Haugen, and Manning (1994) suggests that women are more likely than men to indicate that a simple apology would remedy an accidental transgression. This difference could be a result of the social norms that lead to gender differences in motivation. Men tend to be motivated by needs of power and status enhancement, while women are more concerned with maintaining relationships (see, e.g., Timmers, Fischer, \& Manstead, 1998). Thus, men are more likely to require that the transgressor do something to restore the damaged status or powerlessness that the transgressor inflicted upon the victim, while women are more likely to give the transgressor the benefit of the doubt (Gonzales et al., 1994).

Transgressions with potential legal consequences, either criminal or civil, are obvious examples of situations in which one party has (at least allegedly) harmed another, and where an apology might be an appropriate response by the wrongdoer. However, research on apology in legal contexts has been limited to only a few criminal jury simulations, has focused on the defendant's expression of remorse, and has obtained inconsistent results. Rumsey (1976) gave mock jurors a summarized trial transcript in which an intoxicated driver hit and killed a pedestrian after being told to take a cab by a policeman. In the remorse condition, the defendant was described as "extremely remorseful," and in the no-remorse condition, the defendant was described as "gave no indication of remorse." The defendant who expressed remorse received a significantly shorter prison sentence than the defendant who did not indicate remorse (Rumsey, 1976). These results may be consistent, on a psychological basis, with the equity principle, which states that physical suffering on the part of the defendant leads to greater leniency. Because the expression of remorse may be seen as psychological suffering, remorseful defendants may therefore receive shorter prison sentences (Rumsey, 1976).

However, other research has indicated that remorse does not significantly affect jury decision making. For example, Kleinke, Wallis, and Stalder (1992) manipulated remorse in two studies. In an interview with a convicted rapist, the rapist showed remorse by saying, "I feel bad about it. I'm sorry for the woman and I wish it had never happened." Alternatively, he showed no remorse by saying, "I don't feel one way or another about it. I just did what I had to do." In the second study, a control group was added in which the rapist simply did not mention anything about remorse. When he expressed remorse, the rapist was perceived as having a less negative character, more potential for rehabilitation, and was assigned fewer years in prison; but these effects were not statistically significant.

Crosby, Britner, Jodl, and Portwood (1995) also found that remorse was not a predictor of jury verdicts, even when the defendant's age was manipulated. Crosby et al. gave questionnaires about a defendant found guilty of first-degree murder to former jurors. The defendant's age ranged from 10 to 19, and a parole officer told participants that at the sentencing hearing the defendant either showed signs of remorse or 
showed a complete lack of remorse. Regardless of the defendant's age, a majority of participants voted for execution, and remorse did not predict jurors' verdicts.

Thus, remorse has been found to lessen sanctions in some studies but not in others. One explanation (albeit a speculative one) of these findings is that remorse matters less for relatively severe crimes (rape and capital murder) than for less severe crimes (negligent homicide). Importantly, no study has found that remorse had a negative effect on criminal sanctions, and even when remorse has failed to affect sentencing, remorseful defendants nonetheless tend to be perceived more positively (Robinson, Smith-Lovin, \& Tsoudis, 1994; Taylor \& Kleinke, 1992). This lack of any negative effect of remorse in criminal cases is completely at odds with the general consensus about remorse in malpractice cases - that is, that it would make defendant physicians appear more negligent and lead to worse trial outcomes (Fiesta, 1994; Lowes, 1997).

\section{EXPERIMENT 1}

Because many crimes (e.g., drug offenses) do not have a readily identifiable injured party, civil cases are more likely to involve someone to whom a wrongdoer can direct an apology. In addition, because most civil cases involve negligence (as opposed to intentional acts), they are more likely to involve the sort of inadvertent behavior where apologies are especially appropriate. The present experiment looked at the effects of remorse in a civil case, specifically, a malpractice case. Participants acted as jurors in a case scenario where a defendant physician had been found liable for negligently causing the death of a patient. Participants indicated the amount of money that should be awarded to the patient's widow. The level of the physician's remorse was manipulated. He made no mention of remorse, expressed remorse at the time of the event and again at trial, expressed remorse only at trial, or denied feeling any remorse. Because of the related research done in criminal cases, it was expected that the presence of remorse at trial would positively affect perceptions of the defendant and reduce the monetary damages awarded. However, it was also predicted that in the condition where the defendant showed remorse at the time of the event, as well as at trial, compensation would be higher because the mock jurors would perceive it as an admission of fault.

\section{Method}

\section{Participants}

Participants were 173 undergraduate psychology students (63\% female).

\section{Materials and Design}

Participants received one of four possible case scenarios in which an emergencyroom physician was found liable for malpractice (Jacobs, 1978; an excerpt is provided in Table 1). The physician misread a patient's electrocardiogram and misdiagnosed him with acid reflux rather than a myocardial infarction (MI). The patient (Xavier) 
Table 1. Excerpt of case scenario

Xavier, a 42-year-old man, was taken to a hospital emergency room in 1995 by his wife, Linda, because he was complaining of severe chest pains. The pain was located underneath his breastbone and radiated to both shoulders. In the emergency room, Xavier had an electrocardiogram, which shows the electric waves that cause the heart to beat.

Dr. Treadway, the emergency room physician, sent Xavier home, advising him to take an antacid. When Xavier arrived home he felt worse than he had felt in the emergency room. He was dizzy and started vomiting, and when he collapsed on the floor, his wife called the police and an ambulance returned him to the same emergency room he'd recently left.

When Xavier arrived in the emergency room he was in cardiac arrest-no heartbeat. Another emergency room physician, Dr. Jones, managed to resume Xavier's heartbeat, though the patient's blood pressure was extremely low. He was admitted to the hospital's intensive care unit. When Xavier arrived in the intensive care unit, his heart had again stopped beating. Repeat resuscitation was unsuccessful. Xavier died.

Dr. Treadway and Dr. Jones met with Linda and discussed the events surrounding the death of Xavier. Nothing was mentioned about possible negligence. However, ...Linda sued Dr. Treadway for malpractice. ...Her main case was based on the classic symptoms of a heart attack, which Xavier was complaining about and the abnormal electrocardiogram reading.

was sent home, but returned later in cardiac arrest and died. His wife filed a wrongful death suit, seeking compensation for the loss of her husband. The summary contained testimony from the plaintiff, the defendant, and an expert witness (indicating liability on the part of the defendant).

During the damages phase, the physician's level of remorse was manipulated. In the control condition, the physician did not say anything indicating remorse. In the remorseless condition, he "indicated that he felt no remorse for his actions, and he vehemently continued to deny that the death was his fault." In the remorse condition, he "expressed remorse for the unfortunate death of Xavier. He said he was very sorry that Xavier had died, while neither admitting nor denying that the death was his fault." The early-remorse condition was the same as the remorse condition, except that the defendant also "expressed remorse for the unfortunate death of Xavier" at the time it occurred.

\section{Procedure}

Participants were told to assume the defendant was found liable and to answer how much money to award Xavier's wife for her loss of consortium and pain and suffering. Participants also rated both parties on a number of dimensions, using nine-point Likert scales: overall perception of both parties and their degree of suffering; and the defendant's honesty, competence, and remorsefulness.

Participants took part in the experiment in small groups. They were randomly given one of the four malpractice case scenarios and made their case-related judgments.

\section{Results and Discussion}

Two-way ANOVAs (remorse condition $\times$ gender) were performed unless otherwise specified. One extreme outlier (whose compensation award was ten times greater than the next nearest value) was removed, leaving 172 participants for analysis. 


\section{Manipulation Check}

The remorse manipulation was effective, $F(3,164)=31.99, p<0.001$. Participants perceived the defendant as more remorseful in the remorse $(M=5.65, S D=2.36)$ and early-remorse $(M=5.29, S D=1.80)$ conditions than in the remorseless $(M=2.43$, $S D=1.78)$ and control $(M=2.37, S D=1.56)$ conditions. It is noteworthy that the defendant was perceived as equally remorseful when no mention at all was made of remorse and when he explicitly denied feeling sorry. Thus, participants' default assumption appears to be that malpractice defendants - even ones who have already been found liable for wrongdoing - do not experience much remorse for their actions.

\section{Compensation}

Six participants did not provide usable data on this measure, leaving 166 participants for analysis. The overall mean was $\$ 2,129,831(S D=\$ 5,206,672)$. Table 2 depicts the compensation awards by remorse condition and participant gender. Despite dropping the outlier, the data were still positively skewed and showed positive kurtosis, which are common characteristics of unconstrained damage awards (Greene \& Bornstein, in press). The far-right $(S D)$ column of Table 2 also reflects a degree of heteroscedasticity in the data, owing to the greater variance in cells with higher mean values (these same patterns were observed in experiment 2 ).

There was a marginally significant effect of remorse condition, $F(3,158)=2.57$, $p<0.06$, with participants awarding greater compensation in the remorseless $(M=$ $\$ 2,671,071, S D=\$ 5,660,559)$ and early-remorse $(M=\$ 3,180,500, S D=\$ 8,090,602)$

Table 2. Compensation, experiment 1

\begin{tabular}{lrrrr}
\hline Condition & Mean & Median & \multicolumn{1}{c}{ Range } & SD \\
\hline Remorse & & & & \\
$\quad$ Males & $1,112,500$ & 550,000 & $50,000-5,000,000$ & $1,280,430$ \\
$\quad$ Females & $1,342,269$ & 500,000 & $4,000-15,000,000$ & $2,985,999$ \\
$\quad$ Total & $1,254,738$ & 500,000 & $4,000-15,000,000$ & $2,459,527$ \\
Early remorse & & & & \\
$\quad$ Males & $6,300,357$ & $2,250,000$ & $5,000-50,000,000$ & $12,816,807$ \\
Females & $1,500,577$ & 550,000 & $50,000-12,000,000$ & $2,882,317$ \\
$\quad$ Total & $3,180,500$ & $1,000,000$ & $5,000-50,000,000$ & $8,090,602$ \\
Remorseless & & & & $8,816,350$ \\
Males & $5,453,333$ & $1,000,000$ & $200,000-26,000,000$ & $1,314,181$ \\
Females & $1,125,370$ & 800,000 & $10,000-5,000,000$ & $5,660,559$ \\
$\quad$ Total & $2,671,071$ & 900,000 & $10,000-26,000,000$ & $3,854,434$ \\
Control & & & & \\
$\quad$ Males & $1,764,500$ & 800,000 & $3,000-15,000,000$ & $1,441,710$ \\
Females & $1,312,321$ & 500,000 & $10,000-5,000,000$ & $2,475,072$ \\
$\quad$ Total & $1,463,048$ & 550,000 & $3,000-15,000,000$ & $8,031,422$ \\
Total & & & & $2,243,454$ \\
$\quad$ Males & $3,601,830$ & $1,000,000$ & $3,000-50,000,000$ & $5,206,672$ \\
Females & $1,318,168$ & 500,000 & $4,000-15,000,000$ & \\
$\quad$ Total & $2,129,831$ & 700,000 & $3,000-50,000,000$ & \\
\hline
\end{tabular}


Mean Compensation

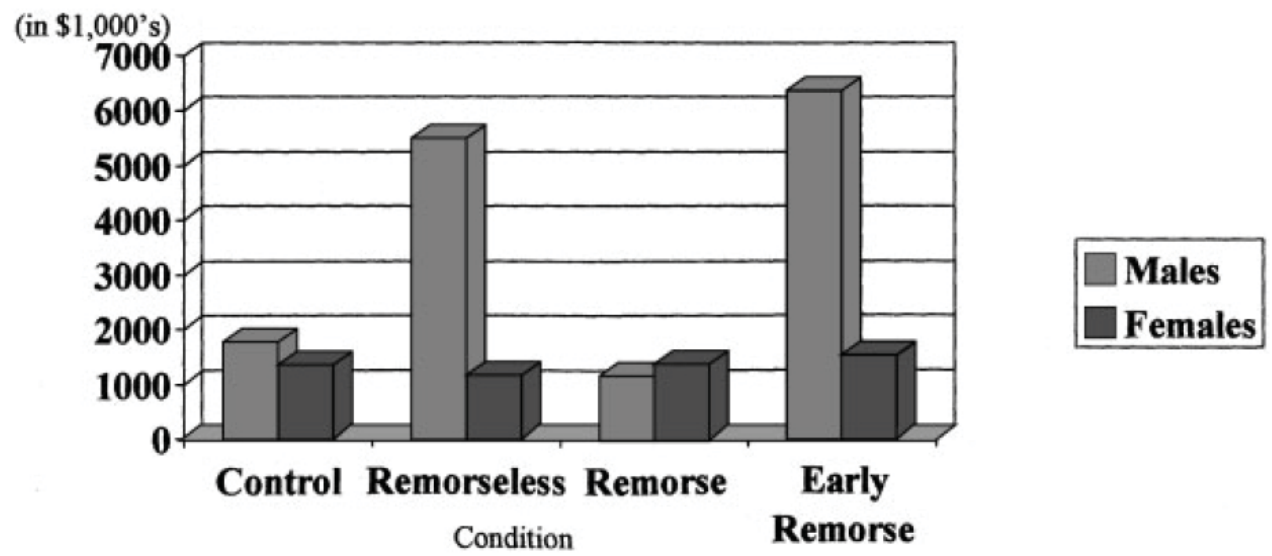

Figure 1. Mean compensation (in $\$ 1000$ s) as a function of defendant's remorse and participant gender, experiment 1.

conditions than in the remorse $(M=\$ 1,254,738, S D=\$ 2,459,527)$ and control $(M=$ $\$ 1,463,048, S D=\$ 2,475,072)$ conditions. Males $(M=\$ 3,601,830, S D=\$ 8,031,422)$ awarded greater compensation than females $(M=\$ 1,318,168, S D=\$ 2,243,454)$, $F(1,158)=8.24, p<0.01$. Males' tendency to award more compensation than females is consistent with males' tendency, in general, to require transgressors to do more to make things up to their victims (Gonzales et al., 1994). A marginally significant interaction, $F(3,158)=2.54, p<0.06$, suggested that males were affected by the defendant's display of remorse, while females were not (see Figure 1).

\section{Perceptions}

Means for the perception measures are shown in Table 3. Two variables assessed the participants' perception of the plaintiff: the overall perception and the degree of suffering (see Table 3 ). Neither varied significantly as a function of the remorse condition, $F \mathrm{~s}(3,164)<1$. Males and females did not differ in terms of their overall perception, but females $(M=8.41, S D=0.84)$ perceived the plaintiff as having suffered significantly more than males $(M=8.12, S D=0.92)$. This result is somewhat surprising in light of the observation that females awarded the plaintiff less compensation than males.

Remorse had a significant effect on participants' overall perception of the defendant, $F(3,164)=4.65, p<0.01$. The nature of the effect was consistent with participants' perception of the defendant's remorsefulness: defendants who showed remorse (i.e., in the remorse and early-remorse conditions) were perceived more favorably than defendants who did not show remorse (i.e., in the control and remorseless conditions). The defendant's remorse did not affect participants' perception of his 
Table 3. Mean perceptions, experiment 1

\begin{tabular}{|c|c|c|c|c|c|c|}
\hline \multirow[b]{2}{*}{ Condition } & \multicolumn{6}{|c|}{ Dependent variable } \\
\hline & $\begin{array}{c}\text { Overall- } \\
\mathrm{P}\end{array}$ & $\begin{array}{c}\text { Suffering- } \\
\text { P }\end{array}$ & $\begin{array}{l}\text { Overall- } \\
\text { D }\end{array}$ & $\begin{array}{c}\text { Competence- } \\
\text { D }\end{array}$ & $\begin{array}{c}\text { Suffering - } \\
\text { D }\end{array}$ & $\begin{array}{c}\text { Honesty- } \\
\text { D }\end{array}$ \\
\hline \multicolumn{7}{|l|}{ Remorse } \\
\hline Males & 5.88 & 8.12 & 4.56 & 4.88 & 6.00 & 6.31 \\
\hline Females & 6.41 & 8.26 & 4.30 & 4.37 & 4.81 & 5.00 \\
\hline \multicolumn{7}{|c|}{ Early remorse } \\
\hline Males & 6.20 & 8.13 & 4.47 & 5.60 & 4.93 & 5.27 \\
\hline Females & 6.37 & 8.52 & 4.52 & 4.85 & 5.07 & 5.15 \\
\hline \multicolumn{7}{|l|}{ Remorseless } \\
\hline Males & 6.00 & 8.13 & 4.07 & 5.47 & 4.87 & 5.33 \\
\hline Females & 6.31 & 8.41 & 3.66 & 4.55 & 4.21 & 4.66 \\
\hline \multicolumn{7}{|l|}{ Control } \\
\hline Males & 5.93 & 8.07 & 3.79 & 4.36 & 5.36 & 5.14 \\
\hline Females & 6.17 & 8.45 & 2.83 & 4.17 & 3.66 & 4.21 \\
\hline \multicolumn{7}{|l|}{ Total } \\
\hline Males & 6.00 & 8.12 & 4.23 & 5.08 & 5.30 & 5.53 \\
\hline Females & 6.31 & 8.41 & 3.80 & 4.48 & 4.42 & 4.74 \\
\hline
\end{tabular}

Ratings were made on a scale from 1 (low) to 9 (high). $\mathrm{P}=$ plaintiff, $\mathrm{D}=$ defendant.

honesty, suffering, or competence, $F \mathrm{~s}(3,164)<2$. However, gender did affect these perceptions: Compared with males, females perceived the defendant as having suffered less, $F(3,164)=6.99, p<0.01$, and as being less honest, $F(3,164)=6.30, p<$ 0.05 , and marginally less competent, $F(3,164)=3.32, p=0.07$ (see Table 3 ). Thus, just as females perceived the plaintiff more favorably, they also perceived the defendant less favorably - even though they awarded the plaintiff less compensation. Females may be more likely than males to give transgressors the benefit of the doubt in some circumstances (Gonzales et al., 1994), but not in others, such as transgressions resulting in legal action.

\section{EXPERIMENT 2}

Wrongful death suits, such as that used in experiment 1 , are an unusual type of tort claim because the principal injury is to someone (the decedent) other than the plaintiff. They are complicated further by the facts that there are statutory limits on what sorts of costs may be recovered, and the decedent's claim is often joined at trial with claims by the decedent's survivors (usually a spouse or child) for their own injuries resulting from the allegedly wrongful death.

Experiment 2 was a replication of experiment 1 using a more traditional (i.e., nonfatal) malpractice claim. It also extended experiment 1 by manipulating the severity of the plaintiff's injury. Injury severity consistently affects civil damage awards more than any other single evidentiary factor (see, e.g., Bovbjerg, Sloan, \& Blumstein, 1989; Bornstein, 1998; Robbennolt, 2000), but it also interacts with a number of substantive and methodological variables (Robbennolt, 2000). Thus, experiment 2 included injury severity in order to address whether the defendant's remorse exerted similar effects across varying degrees of injury. 


\section{Method}

\section{Participants}

One hundred and thirty-four participants (66\% female) received extra course credit for their participation.

\section{Materials and Design}

The case summary was the same as in experiment 1 , except that the patient was described as having survived his MI. There were two levels of injury severity: in the mild injury condition, Xavier's condition stabilized quickly, his hospitalization was relatively brief, and by trial he had apparently made a full recovery. In the severe injury condition, his MI was more serious, his hospitalization was lengthier, and by trial he still suffered continuing effects from the heart attack.

The defendant's remorse was manipulated as in experiment 1 , with four conditions: control, remorse, early remorse, and remorseless. Thus, the design was a $2 \times 4$ between-groups design.

\section{Procedure}

The procedure was identical to experiment 1, except that a question measuring participants' perception of the severity of the plaintiff's injury was added as a manipulation check.

\section{Results and Discussion}

Six extreme outliers were removed, leaving 128 participants for analysis. There were not enough males in each condition to include gender as a variable in the full analyses, which were consequently ANOVAs including only remorse and injury severity as factors. However, analysis of the main effect of gender yielded results consistent with experiment 1: Males awarded greater compensation than females, $t(126)=2.79$, $p<0.01$, yet they also perceived the defendant significantly more positively overall and as having suffered more than females, $t \mathrm{~s}(126)>2.03, p \mathrm{~s}<0.05$ (gender effects on other perception measures were non-significant).

\section{Manipulation Checks}

The remorse manipulation was effective, $F(3,120)=29.16, p<0.001$. As in experiment 1 , participants perceived the defendant as more remorseful in the remorse $(M=$ $5.12, S D=1.96)$ and early-remorse $(M=5.10, S D=2.27)$ conditions than in the remorseless $(M=2.12, S D=1.62)$ and control $(M=1.97, S D=1.36)$ conditions. Neither the main effect of injury severity, nor the interaction between severity and remorse was statistically significant, $F_{\mathrm{s}}<1$. 
The injury severity manipulation was effective as well, $F(1,120)=32.01, p<$ 0.001 . Participants perceived the severely injured plaintiff as more severely injured $(M=7.72, S D=1.08)$ than the mildly injured plaintiff $(M=6.33, S D=1.64)$. The defendant's remorse did not affect participants' perception of the injury's severity, nor was there a significant interaction between remorse and severity on participants' perception of injury severity, $F \mathrm{~s}<1.4$.

\section{Compensation}

The overall mean was $\$ 248,094(S D=\$ 533,713)$, substantially less than the mean compensation awarded in experiment 1 (over $\$ 2$ million) for the same case, but where the patient had died and the damages went to his widow. Figure 2 depicts the compensation awards by remorse condition and participant gender. There was a statistically significant effect of remorse condition, $F(3,120)=3.50, p<0.05$, with participants awarding greater compensation in the early-remorse $(M=\$ 432,903, S D=$ $\$ 937,172)$ condition than in the remorse $(M=\$ 239,574, S D=\$ 332,760)$, remorseless $(M=\$ 190,045, S D=\$ 318,185)$, and control $(M=\$ 137,444, S D=\$ 226,522)$ conditions. Participants awarded greater compensation to the severely $(M=\$ 460,008$, $S D=\$ 704,699)$ than to the mildly injured plaintiff $(M=\$ 55,158, S D=\$ 131,797)$, $\mathrm{F}(1,120)=25.73, p<0.001$. A marginally significant interaction, $F(3,120)=2.54$, $p=0.06$, suggests that the effect of remorse by the defendant was greater for severe than for mild injury (see Figure 2).

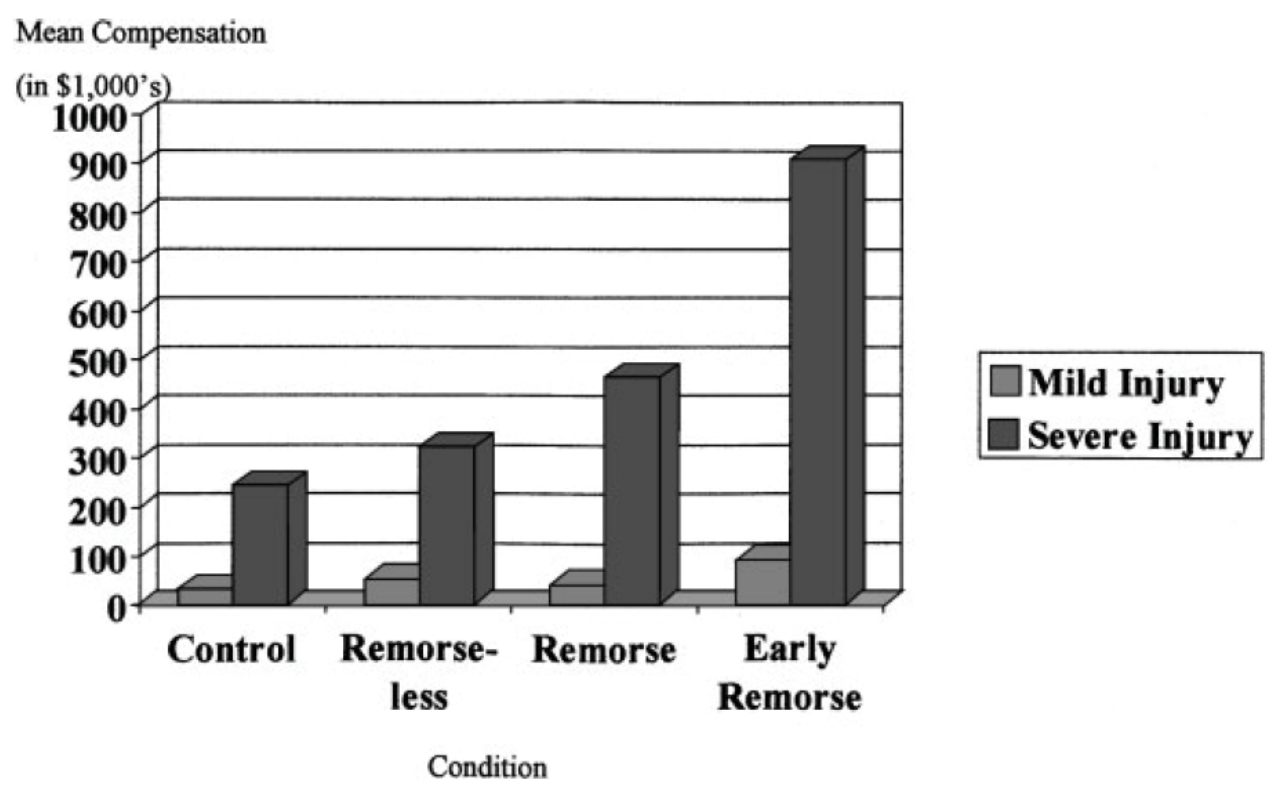

Figure 2. Mean compensation (in $\$ 1000$ s) as a function of defendant's remorse and severity of the plaintiff's injury, experiment 2 . 


\section{Perceptions}

Means for all perception measures are shown in Table 4. As in experiment 1, participants' perception of the plaintiff did not vary significantly as a function of the remorse condition, $F_{\mathrm{S}}(3,120)<1.6$. However, compared with the mildly injured plaintiff, the severely injured plaintiff was perceived as having suffered more, and as more positive overall, $F_{\mathrm{S}}(3,120)>4.1, p \mathrm{~s}<0.05$ (see Table 4 ). These findings are consistent with previous research indicating that relatively severely injured plaintiffs are viewed more sympathetically in general (Bornstein, 1998; Wissler, Evans, Hart, Morry, \& Saks, 1997).

Remorse had a significant effect on participants' perception of the defendant's suffering, $F(3,120)=3.30, p<0.05$. The nature of the effect was consistent with participants' perception of the defendant's remorsefulness: As in criminal cases (Rumsey, 1976), defendants who showed remorse (i.e., in the remorse and early-remorse conditions) were perceived as suffering more than defendants who did not show remorse (i.e., in the control and remorseless conditions). The defendant's remorse did not affect participants' overall perception of the defendant, or their perception of his honesty or competence, $F_{\mathrm{S}}(3,120)<1.5$.

Injury severity had little effect on participants' perception of the defendant. The defendant who was found liable for having caused a severe injury to the plaintiff was perceived as less honest $(M=4.54, S D=1.91)$ than the defendant who was found liable for having caused a mild injury $(M=5.63, S D=1.78), F(1,120)=10.25, p<$ 0.005 ; but injury severity did not significantly affect participants' overall perception of the defendant or their perception of his competence or suffering, $F_{\mathrm{S}}<2.7$. This tendency of a more severe injury to evoke any more negative perceptions of the defendant demonstrates a clear extralegal bias, as the defendant's behavior was identical across the different levels of injury severity.

Table 4. Mean perceptions, experiment 2

\begin{tabular}{|c|c|c|c|c|c|c|}
\hline \multirow[b]{2}{*}{ Condition } & \multicolumn{6}{|c|}{ Dependent variable } \\
\hline & $\begin{array}{l}\text { Overall- } \\
\mathrm{P}\end{array}$ & $\begin{array}{c}\text { Suffering- } \\
\mathrm{P}\end{array}$ & $\begin{array}{c}\text { Overall- } \\
\text { D }\end{array}$ & $\begin{array}{c}\text { Competence- } \\
\text { D }\end{array}$ & $\begin{array}{c}\text { Suffering- } \\
\text { D }\end{array}$ & $\begin{array}{c}\text { Honesty- } \\
\text { D }\end{array}$ \\
\hline \multicolumn{7}{|l|}{ Remorse } \\
\hline Severe inj. & 6.07 & 7.13 & 4.13 & 5.27 & 4.73 & 4.93 \\
\hline Mild inj. & 5.35 & 5.47 & 4.94 & 5.88 & 4.59 & 5.59 \\
\hline \multicolumn{7}{|l|}{ Early remorse } \\
\hline Severe inj. & 5.92 & 7.38 & 4.00 & 5.15 & 5.00 & 4.77 \\
\hline Mild inj. & 5.56 & 6.33 & 4.17 & 5.11 & 4.50 & 5.78 \\
\hline \multicolumn{7}{|l|}{ Remorseless } \\
\hline Severe inj. & 6.06 & 7.47 & 3.82 & 4.24 & 3.53 & 4.06 \\
\hline Mild inj. & 5.31 & 5.88 & 4.75 & 5.44 & 3.75 & 6.00 \\
\hline \multicolumn{7}{|l|}{ Control } \\
\hline Severe inj. & 6.25 & 7.50 & 4.00 & 4.44 & 3.50 & 4.50 \\
\hline Mild inj. & 6.19 & 6.50 & 3.81 & 4.81 & 3.75 & 5.12 \\
\hline \multicolumn{7}{|l|}{ Total } \\
\hline Severe inj. & 6.08 & 7.38 & 3.98 & 4.74 & 4.13 & 4.54 \\
\hline Mild inj. & 5.60 & 6.04 & 4.42 & 5.31 & 4.16 & 5.63 \\
\hline
\end{tabular}

Ratings were made on a scale from 1 (low) to 9 (high). $\mathrm{P}=$ plaintiff, $\mathrm{D}=$ defendant. 


\section{GENERAL DISCUSSION}

The major finding of the present studies is that the defendant's display of remorse affected jury decision making in a simulated malpractice trial. However, the timing of the remorse was crucial. When the defendant expressed remorse at the time of the patient's injury and again at trial, participants awarded the plaintiff more money for compensation; yet when the defendant expressed remorse only at trial, the plaintiff received approximately the same amount of money as when the defendant made no mention of remorse at all. There was some indication that the defendant who explicitly denied feeling any remorse was also punished by having to pay greater compensation, but this effect was observed in only one of the two experiments.

Defendants who made no mention of remorse were perceived as being no more remorseful than defendants who explicitly denied experiencing any remorse, suggesting that mock jurors' default perception of malpractice defendants is as relatively uncaring. In contrast, defendants who showed remorse - regardless of when-were perceived more positively than defendants who were not remorseful. These findings are congruent with the literature showing that remorse leads to favorable perceptions of the transgressor (e.g., Darby \& Schlenker, 1989). This positive effect of remorse has been found for both child transgressors (Darby \& Schlenker, 1989) and adult criminals (Rumsey, 1976; Taylor \& Kleinke, 1992).

It is curious that, despite this more favorable perception, a defendant who apologized at the time of the event and again at trial nonetheless paid more in compensation than a defendant who showed remorse only at trial. This lack of concordance between mock jurors' perceptions and their verdicts has two implications. First, it suggests that, although jurors' verdicts may be driven to some extent by their emotions (Bornstein, 1998; Feigenson, Park, \& Salovey, 1997), their emotional responses are not determinative. Second, it suggests that jurors make inferences from both what defendants say and when they say it. It seems likely that participants took the defendant's remorse at the time of the injury as an admission of wrongdoing or indication of negligence, but that the expression of remorse per se was not interpreted that way. Because participants did not judge the defendant's degree of negligence but only awarded damages after liability had already been established, our data cannot speak directly to this interpretation.

Often, injured parties in litigation seek primarily to find out what happened, to punish wrongdoers for their mistakes, or to foster the development of measures to prevent similar injury to others (Huycke \& Huycke, 1994; Sloan, 1991). Unfortunately, these goals of the injured parties may not be aligned with the goals of the adversarial legal system, resulting in defendants receiving only monetary awards. Further, the adversarial system discourages wrongdoers from apologizing because, in most jurisdictions, it could be used against them by arguing that an apology is an admission of fault (Goren, 2001).

An alternative legal approach that seeks to provide results more in line with the sorts of non-pecuniary results that many injured parties seek is a restorative justice approach. This approach, which is most commonly used in the criminal justice system, holds that "justice cannot be achieved simply by punishing or treating offenders. Rather, justice processes must promote repair or an attempt to heal the wound crime causes" (Bazemore, 1998, p. 769). Restorative justice addresses the needs of both the 
injured party and the wrongdoer, as well as the community as a whole. This process provides an opportunity for the injured party, the wrongdoer and often a member of the legal or therapeutic community to meet with a trained mediator to work out a solution that is best for all parties. Such a process has reportedly had a powerful impact on the lives of those involved, both victims and offenders (Umbreit \& Vos, 2000).

Restorative justice could also be applied to civil lawsuits, such as malpractice cases, in a manner similar to criminal restorative justice processes (Cohen, 1999). The injured party, the accused physician(s), and a representative of the medical community would meet in order to determine the needs of each party. The medical community would work with the physician to take appropriate measures to prevent recurrence of the injury, thus promoting an environment in which the community can feel safe and secure. In something like a more expansive version of the "early-remorse" condition used here, the physician would be given the chance, prior to any legal action, to explain and to apologize, two things that would help the healing process for the injured party. Thus, restorative justice eliminates a "win/lose" situation and encourages a "win/win/win" situation by providing holistic justice involving the wrongdoer, the injured party, and the community.

The effect of the defendant's remorse varied depending on two factors: participants' gender (experiment 1) and the severity of the plaintiff's injury (experiment 2). The effect of remorse was limited to male participants: Males punished defendants who showed remorse at the time of the event (or who denied feeling remorse) by awarding greater compensation in these conditions, whereas females' compensation awards were roughly the same across all remorse conditions. In addition, males awarded greater compensation than females overall in both experiments. This gender difference is consistent with previous research showing that when gender differences are observed - although they usually are not - males tend to be more generous in awarding compensation (Greene \& Bornstein, in press). It might reflect the general fact that in situations of wrongdoing males are more likely than females to require the transgressor to do something to restore the injured party's status (Gonzales et al., 1994). In the civil trial context, the explicit mechanism for such restoration is the awarding of damages. Interestingly, even though males awarded greater compensation to the plaintiff, they tended to perceive the plaintiff in a less sympathetic fashion - and the defendant in a more sympathetic fashion - than did females.

With regard to injury severity, there was an interaction between severity and remorse, such that the effect of remorse occurred for a relatively severe but not for a relatively mild injury. This interaction might have occurred because of a floor effect in the mild injury condition, where the mean award was only $\$ 55,158$ (as compared with the severe injury condition, $M=\$ 460,008$ ); that is, in the mild injury condition, the effect of remorse had less room to operate. It would be interesting to see whether remorse had differential effects for mild and severe injuries where mock jurors were also asked to determine the defendant's liability, and not just to award damages.

\section{Limitations and Future Directions}

The generality of the present research is limited by several factors. First, the mock jurors were undergraduate students - and hence younger and more educated than the 
general population of those eligible to serve as jurors. Although mock jurors' verdicts do not differ substantially depending on whether they are students or a more diverse, community-drawn sample (Bornstein, 1999), some research has found that civil jurors' demographic or attitudinal characteristics have a statistically significant—albeit small - effect on their verdicts (Greene \& Bornstein, in press). Thus, it would be desirable to replicate the present findings with a more diverse sample of mock jurors.

In addition, participants in the present experiments did not deliberate to a consensus verdict, as would jurors in an actual malpractice case. Group damage awards tend to be lower than the awards made by individuals (Davis, Au, Hulbert, Chen, \& Zarnoth, 1997). This finding does not necessarily imply that group verdicts would be affected any less (or more) than individual verdicts by the defendant's display of remorse; but the present results should be replicated with deliberating juries before making strong recommendations to malpractice defendants about how they should behave.

Third, mock jurors only awarded damages, without first determining the defendant's liability (i.e., responsibility). Thus, it is unknown whether their attributions or assumptions about responsibility could have mediated the amount of compensation awarded. Responsibility, or fault, is an important element of how an apology is received (Scher \& Darley, 1997), and future research that includes a liability phase should explore the inferences about responsibility that jurors might draw from a defendant's remorse. Nonetheless, it is valuable to study the processes by which jurors make damage awards in isolation. The damages phase is a particularly unstructured component of civil trials (Greene \& Bornstein, 2000), and the same variables often affect liability judgments and damage awards differently (Greene \& Bornstein, in press).

Fourth, the present study operationalized the defendant's apology in terms of his degree of remorse. Other apology strategies exist, such as admitting fault, promising to avoid future transgressions, and offering to correct the transgression (Scher \& Darley, 1997). Future research should address the effectiveness of these strategies for malpractice defendants relative to a display of remorse. It seems likely that some strategies (e.g., admitting fault) would exert a greater effect on judgments of the defendant's liability, while other strategies (e.g., remorse) would exert a greater effect on the awarding of damages.

\section{Recommendations and Conclusions}

Despite these limitations, we can offer some tentative recommendations. Should physicians apologize for their mistakes? Our findings indicate that a show of remorse at the damages phase of trial does not affect physician defendants adversely. Other research suggests that apologizing earlier can even reduce the chance that a malpractice lawsuit will be filed (Fiesta, 1994; Lowes, 1997), and that it might also restore both the patient's and the physician's sense of justice (Bazemore, 1998; Cohen, 1999). In a non-litigious society, those benefits would be enough to recommend apology as the appropriate response to wrongdoing in medical contexts. However, our results also show that apologizing at the time the adverse event occurs leads to higher damage awards than not apologizing, especially when the injury is relatively severe. In a civ- 
il justice system where such conduct could be used to urge jurors to infer more culpable behavior - as it may be in most American jurisdictions, with a few notable exceptions (e.g., Massachusetts, Texas, California, Vermont) — defendant physicians must unfortunately be very guarded about when and how they display remorse for a patient's negative outcome.

\section{REFERENCES}

Bazemore, G. (1998). Restorative justice and earned redemption. American Behavioral Scientist, $41,768-807$.

Bennett, M., \& Dewberry, C. (1994). "I've said I'm sorry, haven't I?" A study of the identity implications and current restraints that apologies create for their recipients. Current Psychology, 13, $10-21$.

Bornstein, B. H. (1998). From compassion to compensation: The effect of injury severity on mock jurors' liability judgments. Journal of Applied Social Psychology, 28, 1477-1502.

Bornstein, B. H. (1999). The ecological validity of jury simulations: Is the jury still out? Law and Human Behavior, 23, 75-91.

Bovbjerg, R. R., Sloan, F. A., \& Blumstein, J. F. (1989). Valuing life and limb in tort: Scheduling "pain and suffering." Northwestern University Law Review, 83, 908-976.

Cal. Evid. §1160.

Cohen, J. R. (1999). Advising clients to apologize. Southern California Law Review, 72, 10091068.

Crosby, C. A., Britner, P. A., Jodl, K. M., \& Portwood, S. G. (1995). The juvenile death penalty and the Eighth Amendment. Law and Human Behavior, 19, 245-261.

Darby, B. W., \& Schlenker, B. R. (1989). Children's reaction to transgressions: Effects of the actor's apology, reputation, and remorse. British Journal of Social Psychology, 28, 353-364.

Davis, J. H., Au, W. T., Hulbert, L., Chen, X., \& Zarnoth, P. (1997). Effects of group size and procedural influence on consensual judgments of quantity: The example of damage awards and mock civil juries. Journal of Personality and Social Psychology, 73, 703-718.

Deese v. Carroll City County Hospital, 416 S.E.2d 127 (Ga. 1992).

Feigenson, N., Park, J., \& Salovey, P. (1997). Effect of blameworthiness and outcome severity on attributions of responsibility and damage awards in comparative negligence cases. Law and Human Behavior, 21, 597-617.

Fiesta, J. (1994). Communication - the value of an apology. Nursing Management, 25, 14-16.

Goffman, E. (1955). On face-work. Psychiatry: Journal for the Study of Interpersonal Processes, $18,213-231$.

Gold, G., \& Weiner, B. (2000). Remorse, confession, group identity and expectancies about repeating a transgression. Basic and Applied Social Psychology, 22, 291-300.

Gonzales, M. H., Haugen, J. A., \& Manning, D. J. (1994). Victims as "narrative critics:” Factors influencing rejoinders and evaluative responses to offenders' accounts. Personality and Social Psychology Bulletin, 20, 691-704.

Goren, S. (2001). Healing the victim, the young offender and the community via restorative justice: An international perspective. Issues in Mental Health Nursing, 22, 137-149.

Greene, E., \& Bornstein, B. H. (2000). Precious little guidance: Jury instruction on damage awards. Psychology, Public Policy, and the Law, 6, 743-768.

Greene, E., \& Bornstein, B. H. (in press). Determining damages: The psychology of jury awards. Washington, DC: American Psychological Association. 
Huycke, L. I., \& Huycke, M. M. (1994). Characteristics of potential plaintiffs in malpractice litigation. Annals of Internal Medicine, 120, 792-798.

Jacobs, H. B. (1978). The spectre of malpractice. New York: Nationwide.

Kleinke, C. L., Wallis, R., \& Stalder, K. (1992). Evaluation of a rapist as a function of expressed intent and remorse. Journal of Social Psychology, 132, 525-537.

Lowes, R. L. (1997, May 12). Made a bonehead mistake? Apologize. Medical Economics, 94-109.

Mass. Ann. Laws ch. 233, §23D (Lexis 1999).

Orleans, J. F., \& Gurtman, M. B. (1984). Effects of physical attractiveness and remorse on evaluations of transgressors. Academic Psychology Bulletin, 6, 49-56.

Phinney v. Vinson, 605 A.2d 849 (Vt. 1992).

Pipes, R. B., \& Alessi, M. (1999). Remorse and a previously punished offense in assignment of punishment and estimated likelihood of a repeated offense. Psychological Reports, 85, 246-248.

Robbennolt, J. K. (2000). Outcome severity and judgments of "responsibility:" A meta-analytic review. Journal of Applied Social Psychology, 12, 2575-2609.

Robinson, D. T., Smith-Lovin, L., \& Tsoudis, O. (1994). Heinous crime or unfortunate accident? The effects of remorse on responses to mock criminal confessions. Social Forces, 73, 175190.

Rumsey, M. G. (1976). Effects of defendant background and remorse on sentencing judgment. Journal of Applied Social Psychology, 6, 64-68.

Scher, S. J., \& Darley, J. M. (1997). How effective are the things people say to apologize? Effects of the realization of the apology speech act. Journal of Psycholinguistic Research, 26, 127-140.

Schlenker, B. R., \& Darby, B. W. (1981). The use of apologies in social predicaments. Social Psychology Quarterly, 44, 271-278.

Sloan, F. A. (1991). Winners and losers: How medical malpractice disputes are resolved. Journal of American Health Policy, 1, 20-25.

Takaku, S., Weiner, B., \& Ohbuchi, T. (2001). A cross-cultural examination of the effects of apology and perspective taking on forgiveness. Journal of Language and Social Psychology, 21, 144166.

Taylor, C., \& Kleinke, C. L. (1992). Effects of severity of accident, history of drunk driving, intent, and remorse on judgments of a drunk driver. Journal of Applied Social Psychology, 22, 16411655.

Texas Civil Practice and Remedies Code, $\$ 18.061$ (West 2000).

Timmers, M., Fischer, A. H., \& Manstead, A. S. R. (1998). Gender differences in motives for regulating emotions. Personality and Social Psychology Bulletin, 24, 974-985.

Umbreit, M. S., \& Vos, B. (2000). Homicide survivors meet the offender prior to execution: Restorative justice through dialogue. Homicide Studies, 4, 63-87.

Vidmar, N. (1995). Medical malpractice and the American jury: Confronting the myths about jury incompetence, deep pockets, and outrageous damage awards. Ann Arbor, MI: University of Michigan Press.

Weiner, B. (1986). An attributional theory of motivation and emotion. New York: Springer.

Wissler, R. L., Evans, D. L., Hart, A. J., Morry, M. M., \& Saks, M. J. (1997). Explaining "pain and suffering" awards: The role of injury characteristics and fault attributions. Law and Human Behavior, 21, 181-207. 